\title{
Digital Tablets in the Classroom: A Perspective from Students
}

\author{
Alison Velchik \\ School of Education, University of North Carolina at Chapel-Hill \\ 100 E Cameron Ave, Chapel Hill, NC, 27514 \\ Email: avelchik@live.unc.edu
}

\begin{abstract}
Technology has been increasingly incorporated into the classroom environment to enhance the teaching process. Although there is research on the effects and use within the classroom, there is currently a need to investigate ways in which digital tablets such as iPads could be utilized in the classroom by the perspective of students. This study involves a thematic analysis of student essays from the Boston Public School system to examine the perceived utility of digit tablets in the classroom as students respond to an essay prompt inquiring about the potential benefits of a hypothetical digital tablet integration initiative at their school. Students report that digital tablets can be beneficial to teachers in three main areas, including through facilitating learning and communication (StudentTeacher Interactions), improved organization (Teacher Organization), and as a problem-solving tool for the wasting of paper and need for computers (Resolution of Teacher Dilemmas). These findings support the notion of continued professional development to implement and fully utilize digital tablet technology in the classroom.
\end{abstract}

Keywords: technology, classroom, education, iPads, digital tablets

DOI: $10.7176 / \mathrm{JEP} / 11-15-02$

Publication date:May $31^{\text {st }} 2020$

\section{Introduction}

Technology has been increasingly incorporated into academic settings in various capacities. Specifically, K-12 schools across the United States have been adopting one to one computing initiatives including enrolling programs involving laptop computers and digital tablets for both teachers and students (Poll, 2014). Research regarding teacher perceptions of digital tablet use in the classroom has shown mixed results indicating some support for the enhanced learning potential along with considerable concern regarding student off task behavior (Ferguson \& Oigara, 2017) whereas generally students K-12 and in college have reported positive feelings associated with technology being utilized in their school setting (Zucker 2010; Wardley \& Mang, 2016).

A disconnect has been identified in the research with the perceived utility of digital tablets in the classroom setting and their actual implementation by teachers (Clarke \& Zaragell, 2012). Teachers have specifically identified difficulty with implementing various applications to provide content related materials and to track student progress (Blackwell, 2014). Pegrum, Howitt, \& Striepe in 2013 analyzed the ways teachers utilized digital tablets within the classroom from the teachers' perspective. Teachers reported utilizing digital tablets mainly for three purposes including recalling and recording information, to quickly aid in extending knowledge to reinforce or expand a concept in class as needed, and lastly, as a personal tool for reflection and self-evaluation for their own pedagogical techniques (Pegrum, Howitt, \& Striepe, 2013).

It is evident that although digital tablets seem generally well-accepted within the field of education, teachers and the administration are unsure of which ways to fully utilize and implement digital tablets (Clarke and Zaragell, 2012). This study reported that teachers mainly used digital tablets as a means of completing administrative tasks, such as accounting for attendance and grades. The teachers relied upon the digital tablets for easy access to email for communication, and rarely utilized their potential to enrich the curriculum for students. Clarke and Zaragell reported that teachers did not receive sufficient training and that this was the main cause for the lack of integration of technology within the curriculum and classroom. Although digital tablets have the potential to become an added resource to enrich the curriculum as well as a supplemental learning tool, it appears that teachers are not receiving the adequate training required and are therefore not integrating the digital tablets into the curriculum, and instead revert back to their own pedagogical methods from before receiving the tablets (Clarke \& Zaragell, 2012).

The research is overwhelmingly supportive of the notion for digital tablets such as iPads in the classroom, however it is evident that teachers are still unsure and insecure about incorporating them with their existing teaching style and curriculum. The research has not yet currently fully explored the perspective of students to better understand how this emerging technology can enhance their learning and education. Analyzing data from the students' perspective may give new insight into the ways in which training can be directed for teachers to improve their educational strategies within the classroom and utilize digital tablets for more than simply administrative purposes. Students are important stakeholders in the school building and they often can provide insight from a different perspective. This study aims to analyze student essays to better understand ways in which students perceive digital tablets as useful tools within the classroom. The research question addressed in this study asks in what ways do students perceive digital tablets such as iPads as tools for teachers? This research question 
seeks to inform teacher training to better utilize the potential of this technology in the classroom.

\section{Methods}

This study involves a thematic analysis through an emic approach of 200 student essays collected within the Boston Public School system from students in the $4^{\text {th }}$ through $8^{\text {th }}$ grades. The essay prompted students to respond with a persuasive essay either agreeing or disagreeing with a hypothetical ban on digital tablets in their school. Through the persuasive essay, students responded with their thoughts on the potential benefits and utility of digital tablets being utilized within their school. A thematic analysis first involves randomly selecting a sample set of twenty essays in order to analyze emerging themes to develop a preliminary codebook. A research assistant was then trained in the codebook and its application which was tested through a different sample of new data. This method is typically employed to reveal any areas of confusion and miscommunication within the codebook that can be remedied with an improved codebook that can increase its consistent application.

The designer and the research assistant then underwent an inter-rater reliability (IRR) trial in order to test the accuracy and applicability of the codebook to a sample of twenty randomly selected essays to test the reliability of the codebook and inform any revisions that are necessary. Once the codebook was finalized, as seen in Table 1, it was then applied to a new dataset of 200 essays in total.

A random sample of twenty essays was coded by the two raters separately using the codebook and subsequently compared using N'Vivo, a computer analysis soft-ware. This soft-ware computed a kappa which equates to the ratio of agreement of similar coding and the probability of achieving this by chance. This kappa is strategically important to qualitative research as it serves as a reflection in the ability for the codebook to be mastered and accurately applied to a dataset (Viera., Garrett, 2005). If the kappa is high, then that signifies the codebook is able to be interpreted and accurately applied to a dataset.

The overall kappa was .6004 signifying that there was 'moderate agreement' overall between the two raters, according to Figure 1 from Viera \& Garrett, 2005. Upon further examination, it was evident that this kappa was lowered by the two unrelated codes of the original codebook and that the majority of codes had 'almost perfect agreement' between the two raters, as seen in Figure 2. The kappa of high agreement for the other codes signified the solid foundation of a codebook, and after making the aforementioned revisions, the codebook was completed and ready to be applied to a larger dataset.

\section{Findings}

The codebook was then applied to the full sample size of 200 student essays from grades between $4^{\text {th }}-8^{\text {th }}$. Overall, it was evident that students view digital tablets as a helpful and beneficial tool for teachers to use. With 200 essays analyzed, there were a number of essays that responded to the prompt in favor of the ban of digital tablets. These essays were discarded from the dataset as they, although important, did not address the research question for this study on the utility of digital tablets in the classroom. When these essays were removed, the dataset was left with 81 essays. The essays deemed 'relevant' to the research question were essays in which the students disagreed with the ban on the tablets and wrote a persuasive essay in favor of having tablets such as iPads in the classroom and provided facts or examples for ways in which these digital tablets would be beneficial to teachers. Table 2 outlines the frequency of occurrence of the codes within only the relevant dataset.

Table 2 demonstrates more accurately the frequency of occurrence of the codes within the data that reported students' perspectives on the ways in which the digital tablets can be a beneficial tool for teachers, when mentioned. These findings can be grouped together by themes and when doing so, it is apparent that the students recognize three separate themes of ways in which the tablets can assist teachers. The three themes are categorized as TeacherStudent Interactions, Teacher Organization, and Resolution of Teacher's Dilemmas. Each of the codes has been grouped into one of these themes.

The theme Teacher-Student Interaction includes the grouping of the codes Communication, Instructing, and Teaching Aid. Students reported that the digital tablets would be beneficial to teachers especially through enhancing their communicative abilities with their students through sending homework electronically, speaking with students via email regarding assignments or questions about concepts, and easier communication through the reading and understanding of typed assignments, rather than hand-written assignments. Students also reported that teachers could use the tablets within the classroom through direct instruction with the class following along on separate, individual tablets. Concepts such as solar systems or visual support aids such as videos could be accessed during class-time to serve as a resource for the learning material. Lastly for the main theme of Teacher-Student Interaction, students reported that the digital tablets could serve as a Teaching Aid for teachers. Students reported that digital tablets could be beneficial to teachers because a student could search a concept or word on their own while in class. By having the digital tablets as an added resource for information, the students report that the teacher will not have to dedicate so much time to each student's individual questions, thereby being a beneficial tool for the teachers indirectly.

The second theme emerging from the data was the idea of improved Teacher Organization. This refers to the 
grouping of the codes Organization-Teacher, Assignment Accountability, and Turning in Assignments. Coding for Organization-Teacher included reports from students indicating the digital tablets could be a useful tool for teachers to organize lesson plans, notes, assignments, and attendance. Students also reported improved Assignment Accountability as teachers could have electronic gradebooks that would account for students' assignments automatically. The theme of Teacher Organization also included the reports of Turning in Assignments, as students described the tablet's ability to allow students to turn in homework electronically thereby eliminating the worksheets becoming lost or misplaced. The category of Teacher Organization grouped together the reports from students relating to improved organization of notes, the ability to account and grade assignments, and the ability to turn in assignments electronically.

The final category is referred to as Resolution of Teacher Dilemmas. This theme includes the final two remaining codes of Save Paper and School Computers. These two codes occurred frequently as a response to a dilemma the students believe the teachers to be facing. Students reported that the digital tablets would help the teachers save paper because the worksheets, books, textbooks, and tests all used or required paper. By having a tablet, the need for paper would be either eliminated or drastically reduced thereby resolving this dilemma for teachers of wasting paper or killing trees, according to the students. Reports also indicated that by having digital tablets in the classroom, teachers would not have to schedule the computer lab or the laptop cart in the school. It is evident from the data that this is a reoccurring problem for teachers, as the students accounted for the process being stressful and uncertain in gaining access to the computer lab. Students also described the school laptops to be slow compared to digital tablets which would be more efficient and therefore effective in class-time activities, such as research for projects.

In conclusion to the analysis of the research, students have reported an array of areas in which they believe teachers can improve with the help of digital tablets. This research demonstrates that students have witnessed multiple problems and dilemmas within the school system, such as the inconvenience and limited access to computers. Students report that digital tablets can be beneficial to teachers in three main areas, including through facilitating learning and communication (Student-Teacher Interactions), improved organization (Teacher Organization), and as a problem-solving tool for the wasting of paper and need for computers (Resolution of Teacher Dilemmas).

\section{Implications}

The implications of this research breach into school policy, professional development, and teacher pedagogical techniques. Regarding school policy, there appears to be support from students to integrate digital tablets into the classroom setting for a variety of reasons including curriculum enhancement as well as green initiatives to reduce the amount of paper that is used. By identifying the ways in which students have identified tablets as useful tools for teachers, gaps in teacher knowledge and tablet utility can be identified and addressed through professional development and short training sessions to remediate the discrepancies between potential uses and current uses. Through training, teachers would be able to breach into advancing their pedagogical techniques to include deeper exploration of concepts, continued engagement with students through technology integration, and individualized approaches to student learning through independent digital tablet instruction and programming.

\section{Limitations}

Methodological limitations include the small sample size with only 81 essays addressing the research question. This study was also limited in the lack of iterative revision to the codebook. A stronger codebook may have been developed through an additional cycle of software analysis by reapplying the codebook to another sample set with a research assistant. This may have resulted in higher kappas indicating a more precise and accurately applied codebook. Lastly, this study was limited in its scope. A plethora of information was provided through the student essays and a larger study may have addressed more than one research question to better understand the clear didactic tension between the potential benefits of digital tablets in the classroom along with the reported student concerns of cyber-bullying and off-task behaviors that were not addressed in this study.

\section{Future Studies}

As mentioned in the limitations, future studies may analyze the didactic nature of emerging technology to better examine both the potential benefits for learning and teaching as well as the consequences, such as increased risks and occurrences of cyber-bullying and off-task behaviors during academic instruction.

The reoccurring theme of school computers reveals that this could potentially be a larger problem systemwide and this itself could be the subject of further research. The reports of scheduling conflicts and the overall inaccessibility to the school laptops and computer-labs was alarming in the essays and this could be a problem system-wide within the public school systems that needs to be addressed.

Other areas of continued research could analyze the ways in which the digital tablets would directly benefit students as a tool for learning. The essays revealed multitudinous responses which not only highlighted the 
beneficial uses for teachers, but also for students. Ideas such as increased motivation for learning, improved desk organization, and an added resource for supplementing lessons were commonly mentioned as ways in which digital tablets could serve students. Research suggested the benefits for students also included efficiency with project research and homework completion. These would be interesting areas for research, as it relates to the use of digital tablets within the classroom. This potential inquiry of research would overlap to some extent with the research analyzed in this paper, as the teachers' and students' needs are often similar, such as organization.

Lastly, a final area of consideration for continued research would be to analyze the essays that were not coded because they disagreed with tablets being used in the classroom. Some students claimed that digital tablets such as iPads should not be used in schools as they are distracting, increase incidents of unnoticed cyber-bullying, and cost too much money.

\section{Conclusion}

In conclusion, this study was limited by multiple methodological factors however it did address a research question aimed at better understanding and examining the perspective of students and how digital tablets can be a beneficial tool for teachers in the classroom setting. This research breaches into a territory that may help to shape professional development and training sessions for teachers to better understand the broad uses of digital tablets as well as their application within the classroom setting that stretches beyond the current uses of administrative task completion and basic organization. Students identified multiple ways in which digital tablets can enhance their learning as well as resolve a number of dilemmas that students perceive teachers experience regularly. Future research may include understanding the consequences of digital tablets in the classroom, such as rates of cyber-bullying or offtask behaviors. Further research can also analyze ways in which students may directly use digital tablets for learning and may build upon this research analyzing digital tablet use for teachers.

\section{References}

Blackwell, C. (2014). Teacher practices with mobile technology: Integrating tablet computers into the early childhood classroom. Journal of Education Research, 7(4), 1-25. [Google Scholar]

Clarke, G., \& Zagarell, J. (2012). Technology in the classroom: Teachers and technology: A technological divide. Childhood Education.88(2), 136-139.

Ferguson, J., \& Oigara, J. (2017). iPads in the classroom: What do teachers think? International Journal of Information and Communication Technology Education, 13(4), 74-86.

Pegrum, M., Howitt, C., \& Striepe, M. (2013). Learning to take the tablet: How pre-service teachers use iPads to facilitate their learning. Australian Journal of Educational Technology, 29(4).

Poll, H. (2014). Pearson student mobile device survey 2014. Retrieved from http://www.pearsoned.com/wpcontent/uploads/Pearson-K12-Student-Mobile-Device-Survey-050914-PUBLIC-Report.pdf [Google Scholar]

Wardley, L., \& Mang, C. (2016). Student observations: Introducing iPads into university classrooms. Education and Information Technologies, 21, 1715-1732.

Zucker, A. (2010). Computers, schools, and students: the effects of technology. Contemporary Sociology, 39(4), 435-436.

Alison J. Velchik first studied psychology at Roanoke College in Salem, Virginia. After graduating in May 2015, she then pursued a Masters of Education in Prevention Science and Practice in School Counseling at the Graduate School of Education at Harvard University in Cambridge, MA graduating in 2016. She then continued her studies pursuing a PhD in School Psychology at the University of North Carolina at Chapel Hill graduating in 2020. Her major areas of research include technology in the classroom, literacy attainment in elementary students, and the science of thriving and well-being in college students.

\begin{tabular}{|l|l|}
\hline \multicolumn{1}{|c|}{ Kappa } & \multicolumn{1}{c|}{ Agreement } \\
\hline$<0$ & Less than chance agreement \\
\hline $.001-0.20$ & Slight agreement \\
\hline $0.21-.40$ & Fair agreement \\
\hline $0.41-0.60$ & Moderate agreement \\
\hline $0.61 .-0.80$ & Substantial agreement \\
\hline $0.81-0.99$ & Almost perfect agreement \\
\hline
\end{tabular}

Figure 1: Interpretation of Kappas 


\begin{tabular}{|l|l|l|}
\hline \multicolumn{1}{|c|}{ Code } & \multicolumn{1}{c|}{ Kappa } & \multicolumn{1}{c|}{ Agreement (\%) } \\
\hline A1. Communicate & .9958 & 99.98 \\
\hline B1. Turning in Assignment & .7505 & 99.49 \\
\hline B2. Homework Account & 1 & 100 \\
\hline C1. School Computers & .8441 & 98.84 \\
\hline D1. Instructing w Digital Tablet & 0 & 99.55 \\
\hline E1. Organization (General) & 0 & 99.46 \\
\hline E2. Organization (Teacher) & .4714 & 98.68 \\
\hline F1. Save Paper & .9952 & 99.99 \\
\hline G1. Source of Learning & .6392 & 94.17 \\
\hline G2. Teaching Aid & .3102 & 98.22 \\
\hline
\end{tabular}

Figure Two: Kappa Summary for Inter-Rater Reliability Trial

Table 1: Codebook

\begin{tabular}{|c|c|c|c|c|}
\hline Code & Definition & Inclusion & Exclusion & Example \\
\hline $\begin{array}{l}\text { A1 } \\
\text { Communication }\end{array}$ & $\begin{array}{l}\text { Teacher } \\
\text { communicates with } \\
\text { student, fellow } \\
\text { teachers, } \\
\text { administrative staff, } \\
\text { or parents using } \\
\text { tablets. Tablet } \\
\text { facilitates easier } \\
\text { communication for } \\
\text { teacher. }\end{array}$ & $\begin{array}{l}\text { Emailing, } \\
\text { newsletters, posting } \\
\text { on website, sending } \\
\text { announcement or } \\
\text { homework, reading } \\
\text { student } \\
\text { assignments. MUST } \\
\text { include teacher in } \\
\text { exchange. }\end{array}$ & $\begin{array}{l}\text { Grading } \\
\text { homework or } \\
\text { assignments or } \\
\text { receiving } \\
\text { homework. } \\
\text { Excludes } \\
\text { communication } \\
\text { between students. }\end{array}$ & $\begin{array}{l}\text { EX. "it provides a way } \\
\text { to communicate to } \\
\text { school teachers." } \\
\text { EX. "For the kids that } \\
\text { have poor handwriting, } \\
\text { now the teacher can } \\
\text { read what they are } \\
\text { trying to say" }\end{array}$ \\
\hline $\begin{array}{l}\text { B1 } \\
\text { Turning In } \\
\text { Assignment }\end{array}$ & $\begin{array}{lr}\text { Transaction } & \text { of } \\
\text { materials } & \text { sent } \\
\text { electronically } & \text { from } \\
\text { students to teachers. }\end{array}$ & $\begin{array}{l}\text { Teacher receives } \\
\text { homework, projects, } \\
\text { or coursework via } \\
\text { email }\end{array}$ & $\begin{array}{l}\text { Teacher grading } \\
\text { or checking } \\
\text { homework or } \\
\text { coursework }\end{array}$ & $\begin{array}{l}\text { EX. "Also to help } \\
\text { students send projects } \\
\text { to their teachers on the } \\
\text { due date." }\end{array}$ \\
\hline $\begin{array}{l}\text { B2. } \\
\text { Assignment } \\
\text { Accountability } \\
\text { (SUBCODE) }\end{array}$ & $\begin{array}{l}\text { Teachers ability to } \\
\text { check the scores of } \\
\text { homework or } \\
\text { assignments for } \\
\text { grading purposes }\end{array}$ & $\begin{array}{lr}\text { Checking } & \text { if } \\
\text { homework has been } \\
\text { turned it AND/OR } \\
\text { grade } \\
\text { assignments }\end{array}$ & $\begin{array}{l}\text { Excludes } \\
\text { electronic } \\
\text { transaction (see } \\
\text { B1) }\end{array}$ & $\begin{array}{l}\text { EX. "One reason is for } \\
\text { checking if we all have } \\
\text { homework or not." }\end{array}$ \\
\hline $\begin{array}{l}\text { C1. } \\
\text { School } \\
\text { Computers }\end{array}$ & $\begin{array}{l}\text { Any situation in } \\
\text { which teacher has } \\
\text { resolved issue of } \\
\text { conflict with } \\
\text { computer lab or } \\
\text { tablet can be used } \\
\text { instead of school } \\
\text { owned technology } \\
\text { such as laptops. }\end{array}$ & $\begin{array}{l}\text { Issues resolved or } \\
\text { avoided regarding } \\
\text { scheduling, use, or } \\
\text { maintenance of } \\
\text { computers within } \\
\text { the school, } \\
\text { including computer } \\
\text { labs or classroom } \\
\text { laptops }\end{array}$ & $\begin{array}{l}\text { Personal } \\
\text { computers and } \\
\text { laptops at home }\end{array}$ & $\begin{array}{l}\text { EX "If the school didn't } \\
\text { use Ipads the teachers } \\
\text { would fight for the } \\
\text { computer lab" }\end{array}$ \\
\hline $\begin{array}{l}\text { D1. } \\
\text { Instructing W w } \\
\text { Digital Tablet }\end{array}$ & $\begin{array}{l}\text { Teachers ability to } \\
\text { instruct class using } \\
\text { tablet. Teacher and } \\
\text { students both are } \\
\text { using tablet in class } \\
\text { to help with lesson }\end{array}$ & $\begin{array}{l}\text { Students following } \\
\text { teachers instructions } \\
\text { with tablet or } \\
\text { teaching using } \\
\text { tablet to instruct }\end{array}$ & $\begin{array}{l}\text { Students free time } \\
\text { with tablet or iPad, } \\
\text { games, or personal } \\
\text { use }\end{array}$ & $\begin{array}{l}\text { EX. "you forgot your } \\
\text { iPad you won't be able } \\
\text { to participate because } \\
\text { the teachers use the } \\
\text { iPads in classwork a } \\
\text { lot." }\end{array}$ \\
\hline $\begin{array}{l}\text { E1. } \\
\text { Organization- } \\
\text { Teacher }\end{array}$ & $\begin{array}{l}\text { Tablet specifically } \\
\text { helps the teacher } \\
\text { organize }\end{array}$ & $\begin{array}{l}\text { Notes, coursework, } \\
\text { lesson plans, } \\
\text { assignments, } \\
\text { homework }\end{array}$ & $\begin{array}{lr}\text { Excludes } & \text { general } \\
\text { statements } & \text { of } \\
\text { organization } & \text { in } \\
\text { classroom } & \text { or } \\
\text { bystudents. } & \end{array}$ & $\begin{array}{l}\text { EX. "iPad can also help } \\
\text { the teachers plan } \\
\text { everything before it } \\
\text { happens" }\end{array}$ \\
\hline $\begin{array}{l}\text { F1. } \\
\text { Saving paper }\end{array}$ & $\begin{array}{l}\text { Teacher can save } \\
\text { paper }\end{array}$ & \begin{tabular}{ll}
\multicolumn{2}{l}{ Using tablet lessens } \\
amount & of \\
paperwork & or \\
worksheets &
\end{tabular} & $\begin{array}{l}\text { * Must explicitly } \\
\text { indicate the } \\
\text { reduction of paper } \\
\text { use }\end{array}$ & $\begin{array}{l}\text { EX "It would be } \\
\text { beneficial because of } \\
\text { the fact less paper will } \\
\text { be used" }\end{array}$ \\
\hline
\end{tabular}




\begin{tabular}{|l|l|l|l|l|}
\hline \multicolumn{1}{|c|}{ Code } & \multicolumn{1}{|c|}{ Definition } & \multicolumn{1}{c|}{ Inclusion } & \multicolumn{1}{c|}{ Exclusion } & \multicolumn{1}{c|}{ Example } \\
\hline G1. & $\begin{array}{l}\text { Tablet serves as a } \\
\text { Teaching Aid }\end{array}$ & $\begin{array}{l}\text { Students looking up } \\
\text { secondary source of } \\
\text { information which } \\
\text { directly student does not } \\
\text { teacher saves } \\
\text { time/resources }\end{array}$ & $\begin{array}{l}\text { questions instead of } \\
\text { having to ask } \\
\text { teacher }\end{array}$ & $\begin{array}{l}\text { Explicitly reason } \\
\text { that this will help } \\
\text { don't have to ask the } \\
\text { teacher for everything." }\end{array}$ \\
& & & \\
\hline
\end{tabular}

Table 2: Frequency of codes within data supporting digital tablets in the classroom

\begin{tabular}{|l|l|l|}
\hline Code & Number of References & Frequency of Code \\
\hline School Computers & 21 & $25.9 \%$ \\
\hline Communication & 15 & $18.5 \%$ \\
\hline Assignment Accountability & 7 & $8.6 \%$ \\
\hline Organization-Teacher & 5 & $6.1 \%$ \\
\hline Instructing & 4 & $4.9 \%$ \\
\hline Save Paper & 9 & $11.1 \%$ \\
\hline Turning in Assignment & 6 & $7.4 \%$ \\
\hline Teaching Aid & 14 & $17.2 \%$ \\
\hline Total: & 81 & $100 \%$ \\
\hline
\end{tabular}

